\title{
Impacts of soil and water pollution on food safety and health risks in China
}

\author{
Yonglong Lu ${ }^{\mathrm{a}, *}$, Shuai Song ${ }^{\mathrm{a}, 1}$, Ruoshi Wang ${ }^{\mathrm{a}, \mathrm{b}, 1}$, Zhaoyang Liu ${ }^{\mathrm{a}, \mathrm{b}}$, Jing Meng ${ }^{\mathrm{a}, \mathrm{b}}$, Andrew J. Sweetman ${ }^{\mathrm{c}, \mathrm{d}}$, \\ Alan Jenkins ${ }^{d}$, Robert C. Ferrier ${ }^{\mathrm{e}}$, Hong $\mathrm{Li}^{\mathrm{c}, \mathrm{d}}$, Wei Luo ${ }^{\mathrm{a}}$, Tieyu Wang ${ }^{\mathrm{a}}$ \\ a State Key Laboratory of Urban and Regional Ecology, Research Center for Eco-Environmental Sciences, Chinese Academy of Sciences, Beijing 100085, China \\ b University of Chinese Academy of Sciences, Beijing 100049, China \\ c Lancaster Environment Centre, Lancaster University, Lancaster LA1 4YQ UK \\ ' Centre for Ecology \& Hydrology, Wallingford, OX10 8BB, UK \\ e The James Hutton Institute, Aberdeen AB15 8QH, Scotland, UK
}

\section{A R T I C L E I N F O}

Article history:

Received 1 November 2014

Received in revised form 25 December 2014

Accepted 31 December 2014

Available online 17 January 2015

\section{Keywords:}

Water availability

Fertilizer application

Pesticide residues

Heavy metal pollution

Food safety

Cancer villages

\begin{abstract}
A B S T R A C T
Environmental pollution and food safety are two of the most important issues of our time. Soil and water pollution, in particular, have historically impacted on food safety which represents an important threat to human health. Nowhere has that situation been more complex and challenging than in China, where a combination of pollution and an increasing food safety risk have affected a large part of the population. Water scarcity, pesticide over-application, and chemical pollutants are considered to be the most important factors impacting on food safety in China. Inadequate quantity and quality of surface water resources in China have led to the long-term use of waste-water irrigation to fulfill the water requirements for agricultural production. In some regions this has caused serious agricultural land and food pollution, especially for heavy metals. It is important, therefore, that issues threatening food safety such as combined pesticide residues and heavy metal pollution are addressed to reduce risks to human health. The increasing negative effects on food safety from water and soil pollution have put more people at risk of carcinogenic diseases, potentially contributing to 'cancer villages' which appear to correlate strongly with the main food producing areas. Currently in China, food safety policies are not integrated with soil and water pollution management policies. Here, a comprehensive map of both soil and water pollution threats to food safety in China is presented and integrated policies addressing soil and water pollution for achieving food safety are suggested to provide a holistic approach.
\end{abstract}

(c) 2015 Elsevier Ltd. All rights reserved.

\section{Introduction}

China's per capita arable land area is less than half of the world average and per capita arable water is about one quarter of the world average (UNESCO, 2012). As a result, the country simply cannot afford to lose any more available land or water due to increasing problems with pollution. Historically soil and water pollution have been considered separately by environmental policy makers. It is imperative, however, that integrated policies, addressing both soil and water pollution, are formulated for the protection of agricultural production and human health.

Water availability is essential for agriculture, and ensures the sustainable increase of grain yield. The largest threat to food production in China may be the impending water shortage due to the highly uneven distribution of surface water resources, and rising demands from irrigation, population increase, and rapid urbanization (Liu and Diamond, 2005; Li, 2010). Moreover, serious surface water pollution in China

\footnotetext{
* Corresponding author.

E-mail address: yllu@rcees.ac.cn (Y. Lu).

1 S.S. and R.W. contributed equally to this work.
}

not only aggravates the water shortage risk but also leads to grain quality degradation. Most research papers to date have focused on the relationships between crop yield and water resources (Y. Wang et al., 2008; Piao et al., 2010; Peng, 2011), water use efficiency (Deng et al., 2006; Fan et al., 2011), infrastructure (Lohmar et al., 2003), agricultural management (Hu et al., 2006) and climate change (Piao et al., 2010; Grassini and Cassman, 2012; Wei et al., 2014), while few studies have investigated the effects of surface water pollution on grain quality at the national scale. There are clear implications for sustainably managing available water supplies, understanding the nature and magnitude of demands, analyzing the factors affecting water quality, and developing policies to ensure continued growth in agricultural production.

Pesticides have been playing an important role in the success of modern food production since the 1950s (Beddington, 2010; Rahman, 2013). Numerous studies have demonstrated that fertilizer and pesticide use have contributed greatly to improved grain production. However, inefficient use of pesticides can also lead to considerable human risks. Inadequate management of pesticide application in food production constitutes potential occupational hazards for farmers and environmental risks for agricultural ecosystems (Lake et al., 2012; Thuy et al., 
2012). Pesticide residues in grain can directly influence public health via food consumption, and diet-related diseases can result in negative public health consequences (James, 2001; Li et al., 2008). The World Health Organization has reported that unintentional occupational poisoning by pesticides has resulted in several million cases worldwide and provided evidence that pesticides were responsible for severely affecting many aspects of human health (WHO, 1990). Although the current use of pesticides poses potentially less threat to the environment and to humans than before, these adverse impacts are still a major and long-term concern.

Among all types of pollutants reported, heavy metals are considered to present the greatest risk to food safety in China (MEP\&MLR, 2014). The main sources of heavy metals in farmland soils include mining and smelting, sewage irrigation, sludge reuse and fertilizer application (Chen et al., 1999). Due to extensive and nonstandard production processes of some mining and smelting enterprises, large quantities of heavy metals affect farmland through wastewater irrigation, waste transportation, sludge application and atmospheric deposition which has been shown to be particularly important in southern China with abundant mineral resources (Hu et al., in press; Xu et al., 2014). Extensive irrigation with poorly treated water from sewage in China has been employed since the 1950s, with the affected area increasing from $115 \mathrm{~km}^{2}$ in 1957 to 36,000 $\mathrm{km}^{2}$ in 1998 (Huang and Wang, 2009), remaining above $30,000 \mathrm{~km}^{2}$ since then. Sewage irrigation refers to the use of sewage outflow for irrigation purposes without any treatment or with simply solids removed, frequently containing toxic and hazardous substances. In some areas, untreated sewage outflow from small cities has been applied directly to farm fields. Sewage irrigation is an effective method to alleviate the shortage of water resources, however, according to an official survey in the 1980 s, $86 \%$ of the area receiving sewage irrigation did not meet the standards for irrigation water quality, and $65 \%$ of sewage irrigation area was contaminated by heavy metals, of which mercury $(\mathrm{Hg})$, lead $(\mathrm{Pb})$ and cadmium $(\mathrm{Cd})$ were the most serious heavy metal pollutants (Wang and Zhang, 2007; Xin et al., 2011). A recent official nationwide survey also reported that 39 of 55 sewage irrigation areas were contaminated by Cd, arsenic (As) and polycyclic aromatic hydrocarbons (PAHs) (MEP\&MLR, 2014). The accumulation of heavy metals is rapidly increasing especially in farmlands with intensive agriculture and large irrigation systems (Chen et al., 2008; Zhang and Shan, 2008). Meanwhile, waste materials from intensive livestock production, which contain high concentrations of As, zinc $(\mathrm{Zn})$ and copper $(\mathrm{Cu})$, are becoming important pollution sources with the expansion of the animal husbandry industry (Zeng et al., 2013).

Water and soil pollution not only has negative effects on food safety but can also result in increased health risks, and has been implicated in the rise of 'cancer villages'. The term 'cancer village' commonly refers to a village in which the morbidity rate of cancer is significantly higher than the average level, most probably caused by environmental pollution (Liu, 2010). In this paper, we use the systematic data on cancer villages collected with clear description of village name, location, main diseases, water quality, and pollution sources. These data suggest that cancer villages tend to cluster in the eastern China, the most important grain producing region. Widespread environmental pollution, especially water pollution is proposed as a key factor in the occurrence of cancer villages (Liu, 2010; Gong and Zhang, 2013).

\section{Methods}

\subsection{Systems approach}

In this paper, a multifactorial approach was used to define a comprehensive spatial analysis of water and soil pollution threats to food safety. Food safety and security are mostly about that of staple food in China. Rice, wheat and maize are staple food, while fish is consumed as subsidiary in some parts of China but not as staple food in China. Besides that, because of serious river pollution, fish production in China is mostly through aquaculture and mariculture mainly in some regions of eastern China. In cancer villages located near seriously polluted rivers, fish is barely caught locally, so fish consumption is not considered in this paper.

Within the administrative boundary of China, more detailed analyses were undertaken at the provincial and major river basin levels to define 31 discrete areas, excluding Hong Kong, Macao, and Taiwan because of unavailability of suitable data. Statistical analyses were performed with SPSS Statistics V20.0 (SPSS Inc. Quarry Bay, HK). Multiple regressions were used to determine the relationships between application of fertilizer, pesticide and grain yield in past two decades. Spatial distributions of water resources, water and soil pollution, and cancer villages were performed with the Arcmap module in ArcGIS V10.0 software (ESRI, Redland, CA). Life cycle analysis was made of policy evolution process for chemicals and heavy metals management since the 1950s, and social network analysis was made of the relationships among the relevant governing bodies.

\subsection{Dataset}

Data were collected from the following sources: (1) a number of national and provincial statistical databases, including "China Statistical Yearbook," "China Agricultural Statistical Yearbook," "China Environmental Status Bulletin"; and "China Water Resources Bulletin"; (2) national or provincial environmental survey such as the latest Nationwide Soil Pollution Survey Report, and Environmental Quality Report; and (3) the existing research results and methodologies described in respective tables or figures.

\section{Water quality and food production}

\subsection{Water availability for irrigation}

The highly uneven distribution of surface water resources and areas of agricultural production between the North and the South, the East and the West are shown in Fig. S1. Some 40\% of the grain yield is produced in the Yangtze River, Pearl River, southeast and southwest river basins, while there is more than $70 \%$ water resource in these regions. Songhua, Liaohe, and Haihe River Basins in northern China have 20\% of the water resources, but provide nearly $50 \%$ of the country's grain production. Agricultural water use is a major part of all water used annually, sourced from glaciers, surface water, and groundwater. The share of irrigation in total water use has declined from $80 \%$ in the 1980 s to $61 \%$ in 2010 in China (NBS, 2013). Figs. S2 and S3 show a significant correlation between effective irrigation area and crop yield which suggests that irrigation plays an essential role in ensuring food production although it is clear that there is an uneven distribution of water resources, especially in the North with extremely scarce water resource. Effective irrigation area is not simply the area that is irrigated, but refers to the total farmland area where water is available with reasonable access to irrigation facilities. The correlation coefficients between surface water for irrigation and grain yield also demonstrate that surface water irrigation is essential to grain yield (Wang et al., 2013) in Huaihe, Songhua and Liaohe River Basins (Figs. S4, S5). The low correlation coefficients were influenced by the water transfer for irrigation in the Yellow River Basin and Haihe River Basin, low surface water irrigation ratio in the Yangtze River Basin and variations of water use efficiency in the North China Plain. The most serious water shortage in the main grain production areas is located in the North China Plain with $33.8 \%$ of the national arable land but only $3.85 \%$ of the national water resources. As a result, the water table has fallen steadily due to intensive agriculture and industry uses over the past 40 years (Li, 2010; Fan et al., 2011). 


\subsection{Effects of surface water pollution on soil and crop quality}

The emission of industrial wastewater has increased with China's rapid economic growth. Surface water pollution caused by rapid urbanization, industrialization and formation of city clusters has been exacerbated due to a lack of strict environmental management and supervision systems. The emission of sewage (urban and rural sewage) is greater than 60 billion tons every year, with urban sewage treatment rates reaching $77.5 \%$ in 2010 , although it is less than $10 \%$ in rural areas. The majority of untreated sewage is directly discharged into rivers and lakes. As a result, surface water pollution in some basins has increased significantly with the result that much of the water is unsuitable for drinking and even irrigation. Generally, surface water pollution is more serious in the North China than the South China, especially in Haihe River, Yellow River and Huaihe River Basins (Fig. 1). An assessment of $17.6 \times 10^{4} \mathrm{~km}$ long rivers in China in 2010 (NBS, 2013) showed that, in terms of China's water quality standards, nearly $38.6 \%$ of the length of the rivers could not be used as industrial or recreational water sources, with $17.7 \%$ of the length of the rivers not suitable for irrigation. The total amount of urban wastewater emissions has increased from 18 billion tons in 1985 to nearly 37 billion tons in 2013 (SEPA or MEP 1985-2013). The Haihe River basin in the North China Plain is faced with not only serious water shortages but also the most serious surface water pollution (Figs. 1, S6). More than 300 million people rely on hazardous drinking water in China, which costs $2 \%$ Chinese rural gross domestic product for mitigating its health impacts (The World Bank, 2006).

Major grain-producing areas are associated with the main irrigation areas with the most serious surface water pollution (Figs. 1 and S1), as sewage has been used for irrigation because of the shortage of water resources, especially in the North of China. With increasing wastewater emissions, sewage irrigation has become an effective measure to alleviate the shortage of water resource and increase agricultural production (Xia and Li, 1985). However, sewage contains a large number of potentially hazardous materials. As the wastewater derived irrigation water continues to be used as part of inefficient irrigation management, it will continue to add contaminants into soils resulting in the accumulation of hazardous substances in the soils, including persistent organic pollutants, and heavy metals (Abdel-Sabour, 2003; Dere et al., 2007).

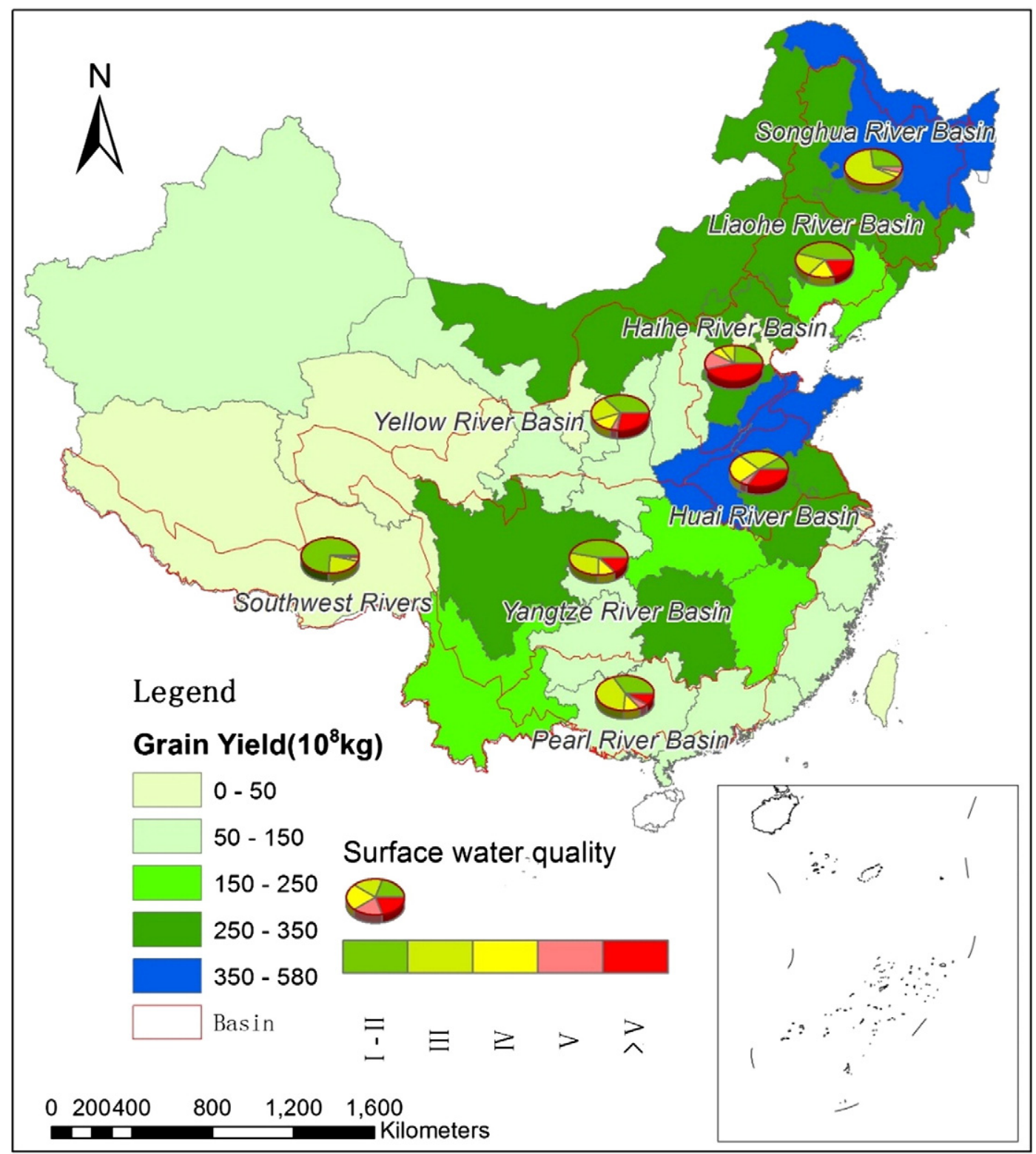

Fig. 1. Distribution of water quality and grain yield in 2010 (note: water quality classification based on Table S7). 
This will continue to degrade grain quality (Al-Lahham et al., 2003; Hassan et al., 2013) and present human health risks through food chain (Singh et al., 2010). Sewage irrigation has distinct effects on quality and nutritional value of crops, evidenced in grain luster becoming darker, less sticky, taste changes and a decrease in protein and amino acid content (S. Jiang et al., 2012). Long-term sewage irrigation and food quality issues have not attracted significant concern by the government, and there is low public awareness of the quality of food stuffs. In 2013, the government, for the first time, prohibited the application of sewage with heavy metals and/or persistent organic pollutants for irrigation (The State Council of China, 2013). However, policy implementation is challenging especially in the North China Plain as a result of the lack of availability of good quality water.

\section{Pesticide and food safety}

\subsection{Pesticide application and grain yield}

Grain protection provided by the use of pesticides has made a significant contribution to growth in agricultural productivity. As shown in Fig. 2, no matter what kind of policy or market adjustment, the total application of fertilizer and pesticides has increased linearly over time with usage doubling over the past two decades (NBS, 2013). Although grain yield grew in the same period, total production has increased only by a quarter with a yield reduction between 1999 and 2003. Reduced production over this period was caused by two factors: firstly, grain fields were used to grow vegetables for higher income so the cultivated area of grain reduced; secondly, more pesticides were used on vegetables while usage of pesticides on grain remained constant. After 2003, the government has carried out a series of policy changes, such as subsidies for seed, fertilizer and pesticide, and removal of the agricultural tax. In 2006, total grain production returned to the level of 1999. It was found that usage of pesticides and fertilizers was positively correlated with grain yield, and that this correlation after 1999 was stronger and of a higher magnitude than that before 1999 (Fig. S7). Due to limited availability of arable land, it is necessary to increase yield per unit area in order to guarantee food safety. Although an integrated pesticide management (IPM) program has demonstrated d that farmers could use fewer pesticides to get higher yields (FAO, 2010), the statistical data from China still confirmed the fact that current production of grain still greatly relies on use of pesticides and fertilizers.
There is a clear increase in the usage of pesticides in those provinces with high grain production, indicating that pesticides still contribute greatly to yield growth (Fig. S8), although some other factors also affect grain yield, including arable land, advancement of agricultural sciences and technology, construction of farm infrastructures, fertilizer use, planting structures for crops, water use, grain price and policy (Zhao et al., 2008; Ericksen et al., 2009). Due to different climate conditions, soil features, grain types and policy changes, inter-annual variation of pesticide applications has showed different increasing trends.

\subsection{Pesticide residues in food}

From 2000 to 2009, pesticide residues in foodstuffs were investigated in China. In 2009, there were 65 pesticides detected in 16 provinces, including 31 organophosphorus pesticides (OP pesticide), 9 carbamate pesticides, 8 pyrethroid pesticides, 9 organochlorine pesticides (OCPs) and 8 herbicides (D. Jiang et al., 2012). These 65 pesticides covered all major historical and currently used agrochemicals. This investigation showed that $\mathrm{OP}$ pesticides are the major products used at present. Although some already banned OCPs and OP pesticides were still present as residues in soils which may continue to impact grain quality. The monitoring data showed that the overall level of contamination decreased and that pesticide residues over prescribed limits declined year by year, from $0.7 \%$ in 2003 to $0.5 \%$ in 2009 . However, pesticide residues in some foodstuffs were still high, either from overuse, illegal use, or use beyond scope of registration, such as carbofuran, methamidophos, parathion.

Impacts from banned pesticides such as hexachlorocyclohexane and its isomers (HCHs) and dichlorodiphenyltrichloroethane and its metabolites (DDTs) are likely to be long-term. Four studies on dietary exposure to OCPs (mainly HCHs and DDTs) for Chinese population were conducted in 1990, 1992, 2000 and 2007 (Chen and Gao, 1993; Liu et al., 1995; Zhao et al., 2003; Zhou et al., 2012). The results showed that dietary intakes of OCPs were 25.52, 14.21, 5.29, and $0.018 \mu \mathrm{g} / \mathrm{kg}$ body wt./day, respectively. The decreased trend highlighted the consequences of prohibition. Among the nine groups of food investigated, aquatic foods, meats and cereals contributed most to total intakes. In addition, the investigation carried out in 2000 showed that HCHs and DDTs in grain were 5.3 and $25.2 \mathrm{ng} / \mathrm{g}$, respectively (Wang et al., 2002), which were much less than similar results observed in 1970-1978 (HCHs, 146 ng/g; DDTs, $24.4 \mathrm{ng} / \mathrm{g}$ ) (Zhao et al., 2003). Although there were still OCPs detected, residues of OCPs in grain and soils generally

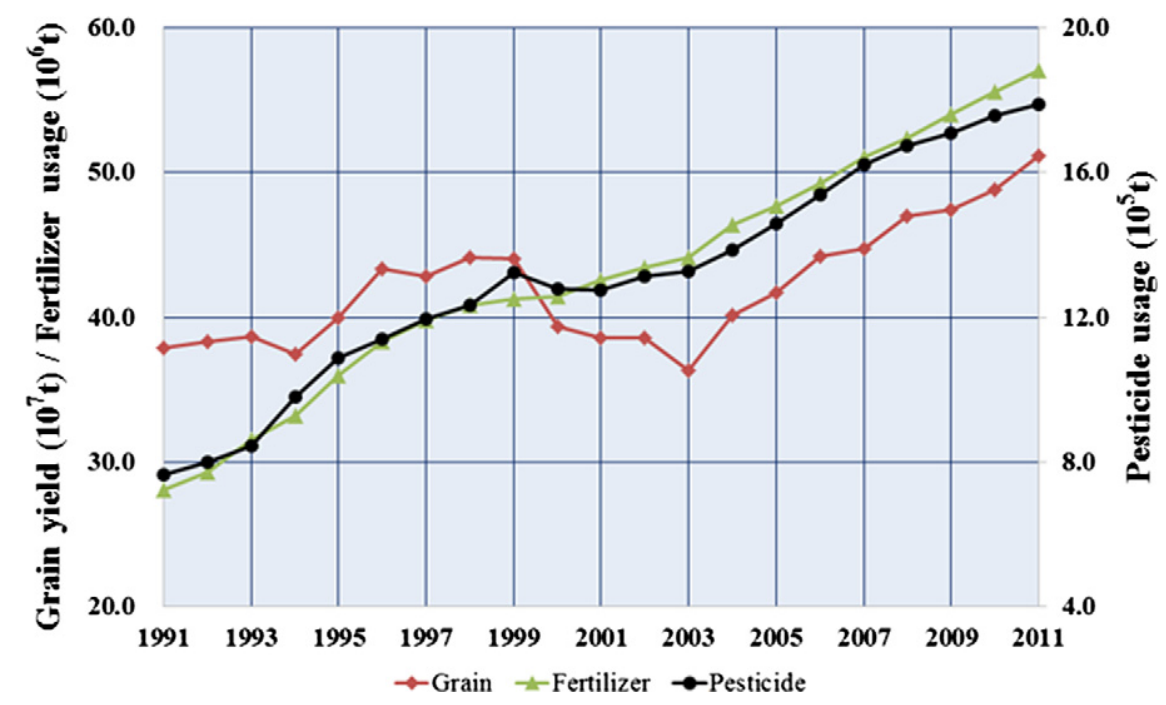

$*$ Grain (including rice, wheat and corn)

Fig. 2. Temporal trend of grain yield $\left(10^{7} \mathrm{t}\right)$, usage of pesticide $\left(10^{5} \mathrm{t}\right)$ and fertilizer $\left(10^{6} \mathrm{t}\right)$ in past two decades. 
showed decreased trend on a national scale. The dietary intakes of DDTs and $\mathrm{HCHs}$ for populations in Beijing and Shenyang were estimated in 2005/2007, and were almost one and two orders of magnitude lower than those in 1992 and in the 1970s, respectively (Yu et al., 2013). One investigation in Hohhot indicated that residues of OCPs in whole wheat plants $(290 \mathrm{ng} / \mathrm{g})$ and corn $(270 \mathrm{ng} / \mathrm{g})$ were higher than those in agricultural soils (185 ng/g), mainly HCHs (Zhang et al., 2013). After the whole plants were divided into three parts, including root, leaf and fruits, concentrations in fruits only accounted for about $0.5 \%$ detected values. Another study concerning the relationship of OCPs in soils and grain was carried out in Jilin (Pan et al., 2011). A significant correlation between residues in stems of rice and corn and that in soils was found, while residues in fruits did not show a similar significant correlation with concentrations in soils. Although HCHs and DDTs have been banned for three decades, residues still posed great risks for animals and humans. After the ban on use of HCHs and DDTs, OP pesticides were widely used, but for some OP pesticides this resulted in high residues in soils. The Ministry of Agriculture has conducted routine inspections for residues of pesticide in fruits and vegetables since 2001, mainly including 13 OP pesticides (Jin et al., 2010), but there is no corresponding inspection in grain. In 2000, four kinds of OP pesticides (methyl parathion, parathion, diazinon, pirimiphos-methy) were detected nationwide, with mean concentrations of $0.540,0.042,0.007$ and $0.002 \mathrm{mg} / \mathrm{kg}$, respectively (Wang et al., 2002). One OP pesticide, namely methyl parathion $(0.540 \mathrm{mg} / \mathrm{kg})$, was found to exceed maximum residue limits (MRL, $0.1 \mathrm{mg} / \mathrm{kg}$ ) although this appeared to be only in one province. Methyl parathion was used to prevent diseases and insects for stored grain in the province. The residues in grain from other provinces did not exceed the MRL. In addition, OP pesticides in grain were also investigated in different provinces and cities (Table S1). Although no uniform method was used, these results demonstrate that residues of $\mathrm{OP}$ pesticides in grain were far beyond the national standards, especially in Hebei and Tongliao.

The increased usage of pesticides has been the major reason for the high residues found in China, with average usage of pesticides per unit area being twice the global average (Yang and Song, 2007). Internationally recognized maximum safe usage of fertilizers is $225 \mathrm{~kg} / \mathrm{ha}$ (CCICED, 2006) but in 2011, average usage of fertilizer in China was $516 \mathrm{~kg} / \mathrm{ha}, 2.3$ times of the safe limit. The average use of pesticides in China was also higher than in other countries. In 2004, the average consumption of pesticides in China was $15 \mathrm{~kg} / \mathrm{ha}$ and higher than those of other Asian countries, such as the Republic of Korea (6.6 kg/ha), Japan (12.0 kg/ha), and India (0.5 kg/ha) (Abhilash and Singh, 2009; Jin et al., 2010). Regulations governing the prohibition of the use of high-toxic and highresidue pesticides were also behind that of developed countries. For example, although the use of OCPs was banned in 1983 in China, this was 10-15 years behind western countries. In addition, there was a lack of knowledge about pesticide use in the farming community which resulted in increased exposure, alongside which the continuous use of pesticides has increased pest resistant, which stimulates even greater over use.

\section{Heavy metals and food safety}

\subsection{Heavy metals in farmland soils}

The growing problem of contamination of farmland and crops by heavy metals has aroused increasing public concern. According to a sampling survey of $3000 \mathrm{~km}^{2}$ prime preserved cropland area in 2000 , $12.1 \%$ of the cropland was with heavy metals concentrations over standards (MEP, 2000). Compared with the result of a national soil background value survey carried out between 1986 and 1990, heavy metal pollutants in surface soils have been increasing significantly (MEP, 2014). As the latest official report concluded, heavy metals were the main pollutants of the $19.4 \%$ farmland soil over standards (MEP\&MLR, 2014). Derived from anthropogenic activities, $\mathrm{Cd}$, nickel (Ni), Cu, As,
$\mathrm{Hg}$ and $\mathrm{Pb}$ are considered to be the most significant heavy metals influencing agricultural soils in China (MEP\&MLR, 2014). In a review study of 12 cities, the concentrations of chromium $(\mathrm{Cr}), \mathrm{Cu}, \mathrm{Pb}, \mathrm{Zn}, \mathrm{Ni}$, $\mathrm{Cd}, \mathrm{Hg}$ and $\mathrm{As}$ in agricultural soils were higher than their background values in most of the cities, among which the mean of $\mathrm{Cd}$ exceeded the maximum permissible concentrations of potential toxic elements (PTE-MPC $0.3 \mathrm{mg} / \mathrm{kg}$ ) with the highest concentration $(2.57 \mathrm{mg} / \mathrm{kg}$ ) found in Xuzhou (Wei and Yang, 2010).

Sewage irrigation is one of the main sources of heavy metal pollution in agricultural soils. Over the last 30 years, there has been reduction of $\mathrm{Pb}, \mathrm{Cr}, \mathrm{Zn}$ and $\mathrm{Ni}$ and increase of $\mathrm{Cu}$ and $\mathrm{Cd}$ in the heavy metal burdens in sewage used for irrigation (Xin et al., 2011). A study in Lechang, Guangdong showed that a paddy field and its rice grain have become heavily contaminated by $\mathrm{Cd}$ as a result of the irrigation with untreated mining wastewater (Yang et al., 2006). In a study of soils and food crops in Beijing, heavy metal concentrations in plants grown in wastewater-irrigated soils were significantly higher than in plants grown in reference soils, with the concentrations of $\mathrm{Cd}$ and $\mathrm{Cr}$ exceeding MEP limits in all plant samples (Khan et al., 2008).

Sources for heavy metals in agriculture soil are also related to cropping patterns (Liu et al., 2011). They demonstrated that the pollution status of heavy metals in rural soils varies under different patterns of cropping, for example, bare vegetable field, greenhouse vegetable field, and grain crop field. Higher contents of total $\mathrm{Cu}, \mathrm{Zn}, \mathrm{Cd}$, and $\mathrm{Pb}$ in soils from four experimental regions (Beijing, Tianjin, Hebei, and Shandong) were found in the bare vegetable field and the greenhouse vegetable field than the grain crop field, which was probably caused by long-term excessive use of chemical fertilizers and organic manures (Huang et al., 2007).

Soil properties and features have been shown to alter crop effects of heavy metals (Zhao et al., 2010). The crop effects of Cd, Pb, Cu and As varied with soil type from region to region. As far as rice yield in the South and North is concerned, considerable variations were found between the soils in subtropical areas in the South and semi-humid areas in north warm temperate zone under heavy metal pressure. Studies which examined changes in rice yields in different soils contaminated with $\mathrm{Cd}$, for example, showed an obvious reduction of yield for rice cultivated in lateritic red soil, red soil and yellow brown soil in the South under low concentrations of $\mathrm{Cd}$, while rice yield was barely affected in brown soil and cinnamon soil in the North (Xia, 1994). Fig. S9 shows the regional differentiation of crop growth affected by Cd and As (intense from light to dark, although no data were available for the green areas) based on the distribution of main soil types in China. In this regard, cropping patterns and soil types should be considered when developing control measures for heavy metal pollution in farmland soils.

\subsection{Heavy metals in crops}

It has been estimated by MEP in 2006 that grain yields have decreased by 10 million tons due to soil contamination, and another 12 million tons of food were found to contain high residues of pollutants, which has resulted in more than 20 billion RMB Yuan of direct economic loss (Zeng et al., 2007; Fu, 2012; Wang et al., 2012). In 2002, the Rice Product Quality Inspection and Supervision Center under the Ministry of Agriculture, conducted a test on the rice safety covering the whole Chinese market. The results showed that $\mathrm{Pb}$ is the most common heavy metal found at levels over maximum residue concentrations in rice at $28.4 \%$, followed by Cd at $10.3 \%$ (Huang, 2012).

Statistic results (Table S2) demonstrate that the problem of grain quality is very serious in each sewage irrigation area, with 31-100\% samples exceeding the Chinese standards for food.

Rice being contaminated by Cd was first reported in 1974, an investigation into the Zhangshi irrigation area in Shenyang city showed that $26 \mathrm{~km}^{2}$ farmland was polluted because the water used for irrigation was the industrial wastewater containing $\mathrm{Cd}$. As a result, the concentration 
of Cd was 3-5 $\mathrm{mg} \mathrm{kg}^{-1}$ in soil, and $0.2-0.4 \mathrm{mg} \mathrm{kg}^{-1}$ in rice (Chen et al., 1980), greatly exceeding the national standards (Table S3). According to studies in Hunan, there is increasing evidence that paddy soils and rice are tainted with $\mathrm{Cd}, \mathrm{As}$, and $\mathrm{Pb}$ in the vicinity of old or currently active large scale mining or ore processing facilities (Williams et al., 2009).

Table 1 presents Cd concentrations for both soil and rice from different regions of China. Comparing these data with Chinese national standards (Table S3), it is clear that Cd concentrations were over the permitted concentrations for some regions, but were not identical for both soil and rice as the $\mathrm{Cd}$ concentrations in rice were also affected by other factors such as soil $\mathrm{pH}$ and soil type.

\subsection{Serious heavy metal contamination events}

Serious heavy metal contamination events have taken place since the 1950s in China, with more frequent occurrences in recent years. The ten most severe events in the last decade are highlighted in Fig. 3. All these extensively reported events caused significant harm to public health or economic losses. The details of each event are shown in Table S4. Those incidents were mostly caused by non-standard openpit mining and smelting processes, which were under no long term control and governance. The agricultural system seems more vulnerable to mining activities (Bai et al., 2011).

In Hunan, one of the major food production regions, these events happened most frequently due to intensive mining activities, which resulted in serious soil and water pollution (Sun et al., 2012). A cultivated site smothered by mining tailings due to the collapse of the tailing dam of a $\mathrm{Pb} / \mathrm{Zn}$ mine in Chenzhou, Hunan, still shows unusual high contents of heavy metals, with As and Cd in the soil exceeding the thresholds specified by the Chinese criteria (GB15618, 1995) by 24 and 13 times and those in the vegetables exceeding by 6.6 and 8.5 times (Liu et al., 2005).

Some of these events have caused serious heavy metal contamination in farmland soils, leading to dramatic decrease or even total loss of crop yields, which may have negative impacts for years. Thousands of villagers living in the surrounding areas are reported to have high heavy metal concentrations in their blood or urine. Heavy metals in water and soil increase the health risk to residents around the location where the event took place, and this risk is then magnified by the accumulation of heavy metals into plants grown in this soil (Zhuang et al., 2009; Zhao et al., 2014).

\section{Pollution related health risks in food production bases}

Long-term exposure to polluted water and soil can have serious environmental consequences as well as health hazards such as diarrhea, abortion, hepatitis A, and typhoid (Bagla, 1996; Cutler and Miller, 2005; Boyle, 2007; Hendryx et al., 2010; Zhang et al., 2010; Grant

Table 1

Cd concentrations in soil and rice from farmland in different regions (1992-2013).

\begin{tabular}{lcllll}
\hline Area & $\begin{array}{l}\text { Cd in soil } \\
\left(\mathrm{mg} \mathrm{kg}^{-1}\right)\end{array}$ & $\begin{array}{l}\mathrm{Cd} \text { in rice } \\
\left(\mathrm{mg} \mathrm{kg}^{-1}\right)\end{array}$ & $\mathrm{pH}$ & $\mathrm{n}$ & References \\
\hline Xingtang, Hebei & 4.78 & 0.5 & 7.8 & - & Chen et al. (1992) \\
Shenyang, Liaoning & 4.09 & $0.1-0.4$ & 6.5 & - & \\
Dayu, Jiangxi & 1.95 & $0.07-1.55$ & 5.2 & 58 & \\
Guangxi 1 & 16.0 & 0.95 & 4.9 & 193 & Lin (1997) \\
Guangxi 2 & 10.0 & 0.30 & 5.2 & & \\
Guangxi 3 & 3.6 & 0.19 & 5.0 & & \\
Middle Hunan & 8.30 & 1.29 & - & 43 & Peng et al. (1992) \\
Lanzhou, Gansu & 9.69 & 0.72 & - & - & Wang (1997) \\
Guangzhou, Guangdong & 6.67 & 0.80 & - & - & \\
Yunnan & 1.52 & 0.64 & - & - & \\
Zhejiang & 6.69 & 1.17 & - & - & \\
Yanghe River, Hebei & 1.56 & - & 8.46 & 36 & Xu et al. (2011) \\
Coastal area of Southern & 0.14 & - & - & 37 & Xu et al. (2013) \\
$\quad$ Bohai Sea & & & & & \\
\hline
\end{tabular}

et al., 2012; Naik and Stenstrom, 2012; Kelepertzis, 2014). Heavy metals, nitrites and organic pollutants in contaminated water and soil could increase the potential risk of cancers (Montesano and Hall, 2001; Hansen et al., 2003; Galiani et al., 2005; Wild et al., 2006; He, 2013). It is reported that contaminated water and food could even increase the morbidity and mortality of cancers, especially digestive cancers (Baudouin et al., 2002; Boffetta, 2006; Beaumont et al., 2008; El-Tawil, 2010; Gallagher et al., 2010; Ebenstein, 2012; Gao et al., 2012; Sun et al., 2014; Zhang et al., 2014; Zhao et al., 2014).

In the seriously polluted regions of China, cancer villages tend to be geographically clustered. The term "cancer cluster" is defined as a greater-than-expected number of cancer cases that occurs within a group of people in a geographic area over a period of time, which is largely due to cancer-causing chemicals (USCDC, 2013). Cancer clusters have become a global phenomenon since 1960 and have been reported in developed countries such as United States, Israel and Italy (Robinson, 2002; Kingsley et al., 2007; Bilancia and Fedespina, 2009; Eitan et al., 2010; Goodman et al., 2012). China's cancer villages and cancer clusters in farming villages, emerged in the 1980s, went through a rapid increase in the 1990s, and the trend continues to increase after 2000 (Yu and Zhang, 2009). Digestive and respiratory cancers, like liver cancer, lung cancer, esophagus cancer, gastric cancer are frequently found in cancer villages (Yu and Zhang, 2009; Ebenstein, 2012). Cancer villages have attracted wide attention from the media and environmentalists (Griffiths, 2007; Kahn and Yardley, 2007; Watts, 2010).

According to China's official sources, there are more than 400 cancer villages in China (Gao, 2013), but no detailed data on their distribution. In this paper, we use the latest government supported investigation data to map out the spatial distribution of cancer villages in China (Gong and Zhang, 2013).

There is a close relationship between the locations of China's major rivers and that of cancer villages (Watts, 2008). Cancer villages tend to cluster along the major rivers and their tributaries, especially in rural areas. Fig. 4 demonstrates that cancer villages in China are mainly located in the Haihe River Basin, mid-lower Yellow River Basin, Huaihe River Basin, mid-lower Yangtze River Basin and Pearl River Delta (Table S5). These rivers support a high density of population and are also prime locations for a wide range of industries with comparatively cheap water, labor and transportation. Many industrial parks are located in these areas (He et al., 2014). Large amounts of industrial, agricultural and domestic waste water have been discharged into the rivers and lakes.

Comparing the distribution of grain production in different provinces with that of cancer villages, the results show that the areas with high morbidity from cancers are located in China's major grain producing areas (Fig. 5). The locations of dense cancer villages in Jiangsu, Anhui, Jiangxi, Hunan, Hubei and Guangdong provinces coincide with the major rice producing areas in China. The major wheat producing areas in Hebei, Henan, Shandong and Jiangsu are also the areas of most densely distributed cancer villages. The main maize producing areas in Hebei, Henan and Shandong provinces also coincide with the areas of most densely distributed cancer villages. The results indicate that the grain production in the provinces containing the most cancer villages accounts for $57.8 \%$ of national total grain production, while the rice yield in these areas accounts for $64.8 \%$ of the total rice yield and wheat yield accounts for $81.0 \%$ of the total wheat yield, maize yield accounts for $41.2 \%$ of the total maize yield (Table S6). China's encouragement of the development of township and village industries in the 1980s has caused severe pollution in these areas (M. Wang et al., 2008), with water shortages aggravating pollution in Hebei, Henan and Shandong provinces which coincide with the locations of many cancer villages.

According to the State of the Environment Report, 23 million tons of chemical oxygen demand and 2.4 million tons of nitrogen oxides was discharged in 2013 (MEP, 2013). About 70\% of China's surface water has been found unsuitable for drinking (The World Bank, 2006), while many farmers rely on this kind of water for drinking (The World Bank, 


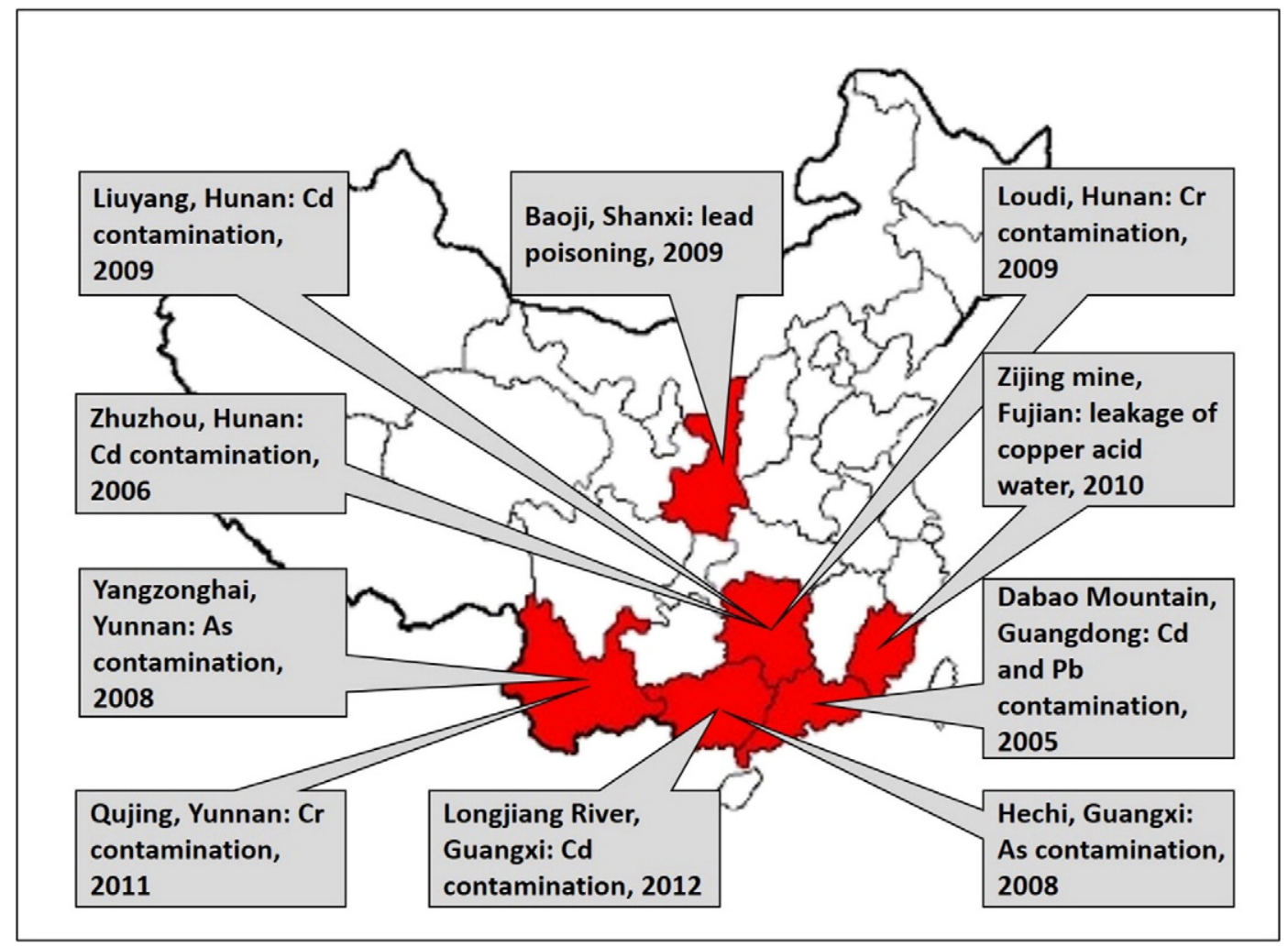

Fig. 3. Ten most severe heavy metal contamination events in the past ten years.

2006; Ebenstein, 2012; Kelepertzis, 2014; Zhang et al., 2014). The cancer morbidity in rural areas is higher than urban areas because urban residents primarily use treated water for drinking, while most rural residents use untreated water for drinking (Zhang et al., 2014). Concurrent with the decline in water quality in China's lakes and rivers, the country has experienced an increase in rural cancer rates in the 1990s (Ebenstein, 2012).

It is reported that digestive cancer mortality has a close relationship with water quality and distance from rivers (Hendryx et al., 2012). Esophageal cancer mortality had a significant positive correlation with widespread water pollution and a negative correlation with buffer distance from polluted rivers and lakes (Zhang et al., 2014). Nearly 60\% of the cancer villages are located less than $3 \mathrm{~km}$ from a major river, while $81 \%$ are distributed less than $5 \mathrm{~km}$ from a major river (Gong and Zhang, 2013).

Morbidity and mortality of gastric or esophagus cancers along polluted rivers are significantly higher than those far away from polluted rivers, and about $80 \%$ of esophagus cancer cases are distributed within a distance of $10 \mathrm{~km}$ from polluted rivers (Massaquoi et al., 2014; Zhang et al., 2014). Cancer mortality exhibited higher correlations with water quality grades than with distance from rivers and lakes (Ebenstein, 2012; Hendryx et al., 2012; Gao, 2013; He, 2013; Massaquoi et al., 2014; Zhang et al., 2014). It is estimated that a deterioration of water quality by a single grade increases digestive cancer death rate by 9.7\% in China, which rules out other potential explanations such as smoking rates, dietary patterns, and air pollution (Ebenstein, 2012).

\section{Integrated approaches for addressing effects of soil and water pollution on food safety and health risk reduction}

Water scarcity and pollution, pesticide over-application, and chemical pollutants are considered to be the most important factors impacting on food safety in China. Inadequate quantity and quality of surface water resources in China have led to the long-term use of wastewater irrigation to fulfill the water requirements for agricultural production. In some regions this has caused serious agricultural land and food pollution, especially for heavy metals. It is important therefore, that issues threatening food safety such as combined pesticide residues and heavy metal pollution are addressed to reduce risks to human health. The increasing negative effects on food safety from water and soil pollution have put more people at risk of carcinogenic diseases, potentially contributing to 'cancer villages'. Currently in China integrated food safety policies are rare from the perspective of soil and water pollution. Future policies need to address this and integrate all the related factors comprehensively.

An integrated nation-wide survey and information infrastructure is needed to investigate soil and water pollution, and food security and safety. In China, baseline data is a bottleneck in addressing the relationship between contaminant emissions, multi-media pollution, food quality, and health problems. To fill this gap, a national-scale integrated water-soil environmental monitoring network should be established to collect real time information on emission sources, major pollutants, and their distribution pathways in different environmental media, and a food safety monitoring system should be established, along with the development of portable detection devices that work more quickly and efficiently to provide more comprehensive information of food safety (Cassiday, 2010). Most importantly, a food supply chain tracking system from field to fork should be established to make the information of food production, processing, transportation and storage open and transparent, and to take precautionary approaches to avoid the spread of contaminated food. Improving monitoring, regulatory oversight and more government transparency are needed to better estimate the potential risks of contaminated water, soil and poor sanitation and hygiene on human health (Wu et al., 1999; Carlton et al., 2012).

A long term systematic and interdisciplinary research program should be conducted on soil and water pollution, food safety, and human health. Since there is a complex relationship between health risk (e.g., cancer), population genetics, and environmental influences, including occupation 


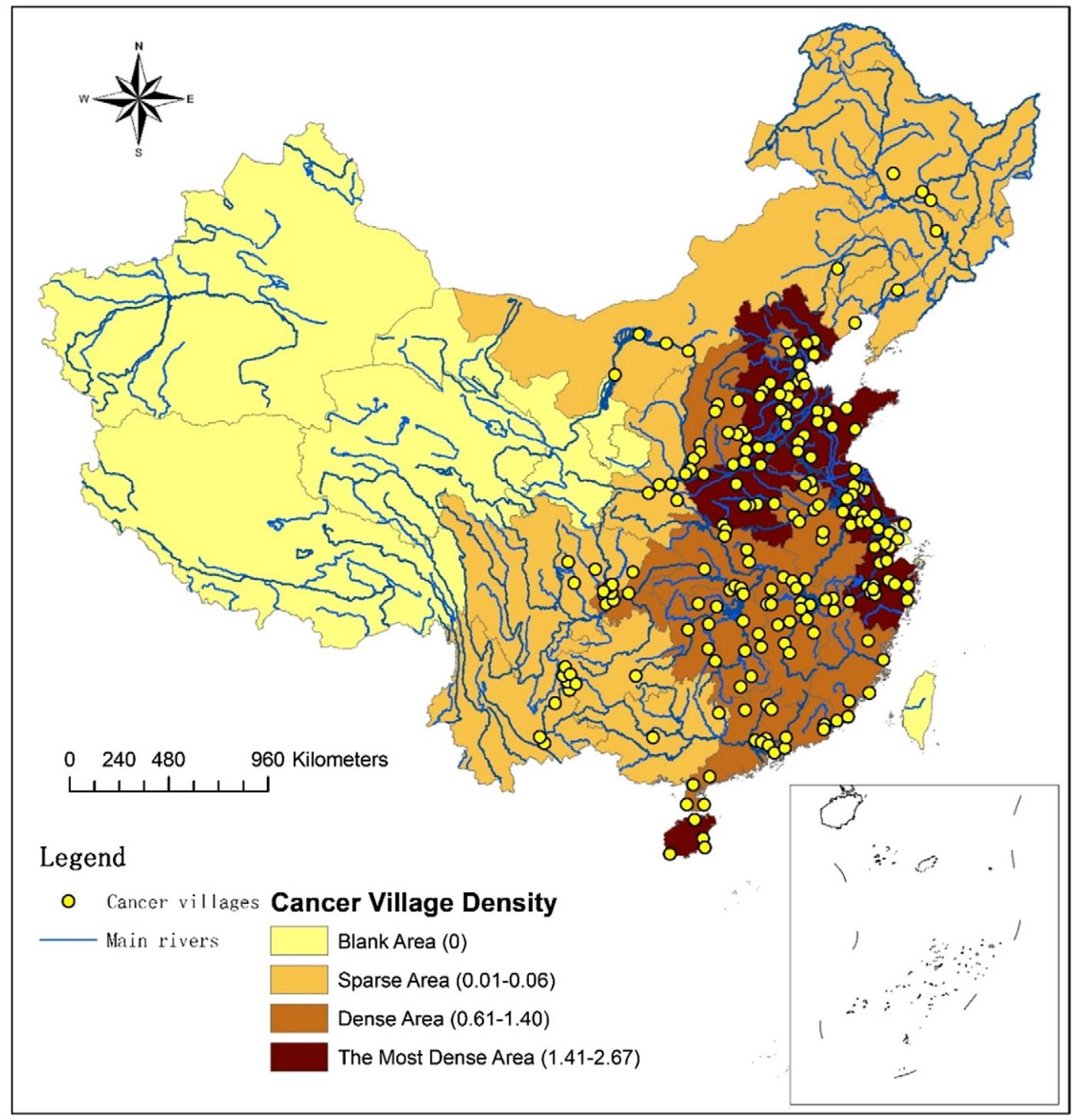

Fig. 4. Distribution of cancer villages and major rivers in China.

exposure, we need to enhance research into the relationship between environmental epidemiology and water-soil pollution, and understand the mechanisms by which human health impacts arise from heavy metal, toxic and hazardous organic pollutants. Science must provide the facts of possible causes and the processes leading to human health risks. It is clear that the chain of cause and effect requires much more research and investigation. For example, the transport of heavy metals and chemical contaminants from soil to food varies depending on a number of factors, such as soil physicochemical properties and cropping systems and more controlled studies are needed to examine the relationship quantitatively. In addition, water quality parameters most often do not include carcinogenic substances, and hence, cannot be directly implicated as a cause of cancer. Therefore, it is essential to systematically examine the temporal and spatial distribution of data pertaining to China's water quality, soil pollution, food contamination, and public health indices (including but not limited to cancer) at national level. To understand the cancer village phenomenon, we need to further explore if there is a pattern between the emergence of cancer villages and the development of certain economic sectors for given regions, and to examine cancer morbidity and mortality of the country's rural vs urban populations given differences in their food and water systems. Key questions on which metals or pesticides or emerging pollutants, at which concentrations/exposure levels and exposure routes cause cancer or other health risks should also be addressed.

A portfolio of policy actions would greatly aid China in resolving water-soil pollution, food safety and health risk problems.

1) It is necessary to strengthen coordination and cooperation between different sectors to reduce duplication of effort and improve interAgency collaboration because at present there are many departments with a role in managing water, soil, food and health. Management of food safety should be viewed as a life cycle process beginning from productive factors, for example, taking water and soil quality into serious consideration.

2) The jurisdictions of environmental management systems and water resources management systems in China are separate. There are seven river basin conservancy commissions in China which are only responsible for water resources transferred in the watershed, rather than water pollution, while provincial environmental protection departments are responsible for provincial pollution control. A new environmental protection department should be established under the river basin conservancy commissions to integrate water pollution, water resources transfer and soil erosion management. Integrated assessment indicators and water pollution control targets in the 


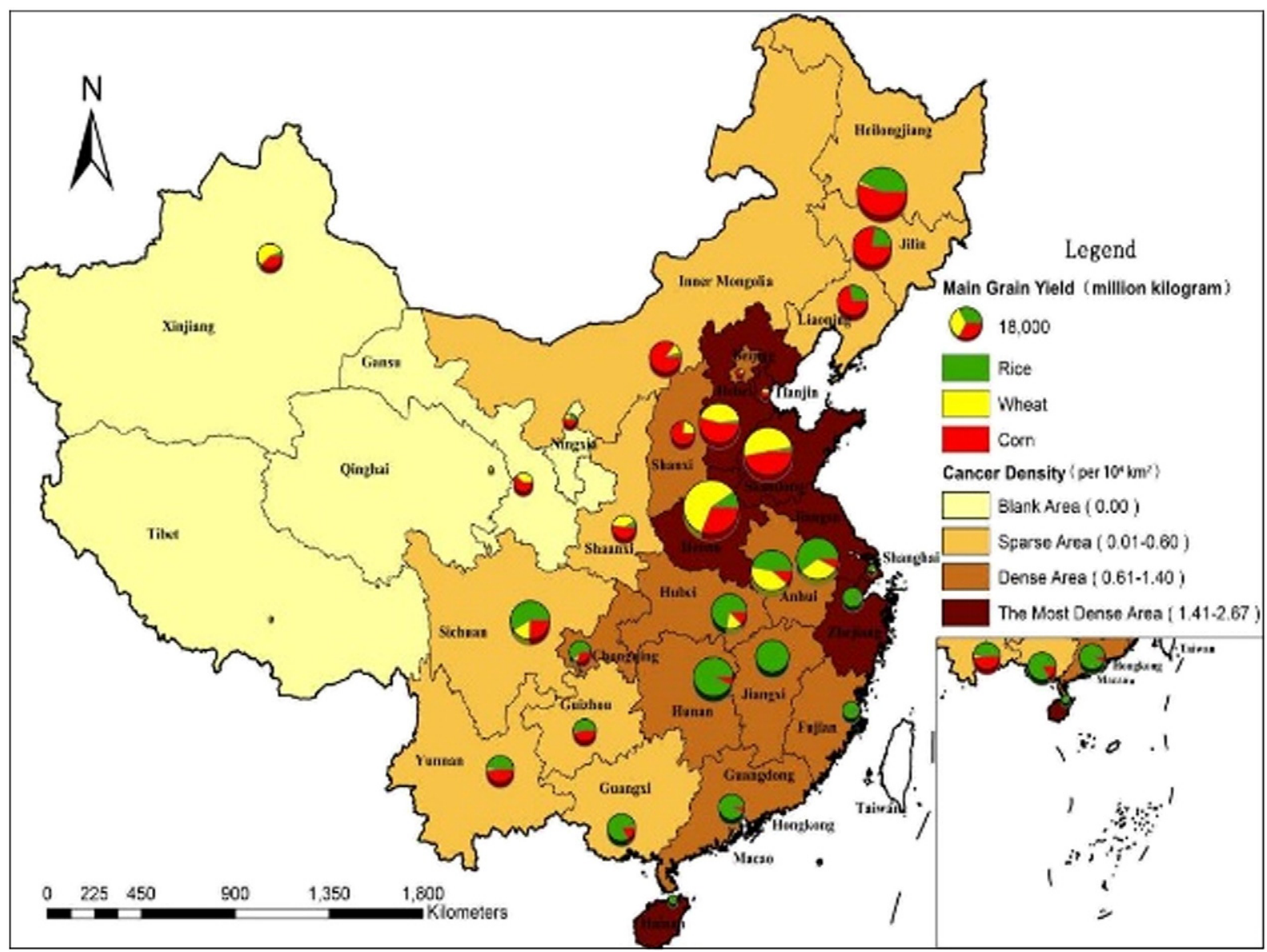

Fig. 5. Distribution of cancer villages and main grain yield in China.

upstream and downstream should be established, and managed by a new environmental protection department.

3) Reduced application of agrochemicals to achieve food safety, along with the development of emission inventories and life-cycle analysis which are all important to control pollution. It has become increasingly urgent to publish a series of guidelines and to establish a standard monitoring system for the whole life cycle of chemicals. The development of clean technologies and alternatives for persistent and highly toxic chemicals should be encouraged through economic incentives such as tax rebates.

4) High risk industries should be relocated far from food production regions. According to the local soil and water features, cost-effective technologies should be applied to improve production processes and reduce pollutant emissions. Collaboration among the government, academia, industry and farmers is essential to foster innovations in improving soil and water quality.

The Chinese government should, as a matter of urgency, turn the passive environmental policy making to a pro-active one. Traditionally, environmental policy changes have been driven by external pressure in China and new policies have normally been set up to address environmental issues as an export barrier or as a by-product of a very serious pollution accident. However, this kind of remedial policy making does not protect against or prevent the occurrence of environmental accidents and, what's more, some losses are irreparable or will take a long time to restore, such as heavily contaminated soil and its resulting adverse human health effects. In this regard, the forward thinking of policy-makers and an efficient early warning system of potential environmental problems are both needed, and policy making needs to focus more on prevention at source. In addition to pesticides and heavy metals, an increasing number of emerging contaminants are posing a threat to food safety, such as persistent organic pollutants. Future pollution control policies for agriculture and food production need to be more comprehensive and multiform, dealing with the effects of combined pollutants. In the meantime, the urgent development of standards to protect the Chinese environment and public is required with regular updates to ensure that emerging contaminants are considered. There is much to learn from China's experience for the nation's own sake as well as for the rest of the world, particularly developing countries.

\section{Acknowledgment}

This study was supported by the International Scientific Cooperation Program with Grant No. 2012DFA91150, the National Natural Science Foundation of China under Grant Nos. 414201040045 and 41371488 , and the Key Project of the Chinese Academy of Sciences under Grant No. KZZD-EW-TZ-12. We are grateful to the support from UK Science and Innovation Network and the Scottish Government's Rural and Environment Science and Analytical Services Division (RESAS) as part of the 'Food Production and Environmental Sustainability in China' project (GPF 13-108), and to the UK Natural Environment Research Council for support via CEH National Capability. We would like to thank the editors and reviewers from Environment International and Nature for their valuable comments and suggestions.

\section{Appendix A. Supplementary data}

Supplementary data to this article can be found online at http://dx. doi.org/10.1016/j.envint.2014.12.010. 


\section{References}

Abdel-Sabour, M.F., 2003. Impact of wastewater reuse on cobalt status in Egyptian environment. J. Environ. Sci. 15, 388-395.

Abhilash, P.C., Singh, N., 2009. Pesticide use and application: an Indian scenario. J. Hazard. Mater. 165, 1-2.

Al-Lahham, O., EI-Assi, N.M., Fayyad, M., 2003. Impact of treated wastewater irrigation on quality attributes and contamination of tomato fruit. Agric. Water Manag. 61, 51-62.

Bagla, P., 1996. Epidemiology - India's spreading health crisis draws global arsenic experts. Science $274,1451$.

Bai, J., Xiao, R., Gong, A., Gao, H., Huang, L., 2011. Assessment of heavy metal contamination of surface soils from typical paddy terrace wetlands on the Yunnan Plateau of China. Phys. Chem. Earth Sci. 36, 447-450.

Baudouin, C., Charveron, M., Tarroux, R., Gall, Y., 2002. Environmental pollutants and skin cancer. Cell Biol. Toxicol. 18, 341-348.

Beaumont, J.J., Sedman, R.M., Reynolds, S.D., Sherman, C.D., Li, L.-H., Howd, R.A., et al., 2008. Cancer mortality in a Chinese population exposed to hexavalent chromium in drinking water. Epidemiology 19, 12-23.

Beddington, J., 2010. Food security: contributions from science to a new and greener revolution. Philos. Trans. R. Soc. Lond. Ser. B Biol. Sci. 365, 61-71.

Bilancia, M., Fedespina, A., 2009. Geographical clustering of lung cancer in the province of Lecce, Italy: 1992-2001. Int. J. Health Geogr. 8, 40-40.

Boffetta, P., 2006. Human cancer from environmental pollutants: the epidemiological evidence. Mutat. Res. 608, 157-162.

Boyle, C.E., 2007. Water-borne Illness in China. China Environmental Health Project, Research Brief. Woodrow Wilson International Center for Scholars, Washington, DC

Carlton, E.J., Liang, S., McDowell, J.Z., Li, H., Luo, W., Remais, J.V., 2012. Regional disparities in the burden of disease attributable to unsafe water and poor sanitation in China. Bull. World Health Organ. 90, 578-587.

Cassiday, L., 2010. Public health: food-safety sentinels. Nature 468, 857-858.

CCICED (China Council for International Cooperation on Environment and Development), 2006. Environmental Issues and Countermeasures Facing New Rural Development in China.

Chen, J., Gao, J., 1993. The Chinese total diet study in 1990. Part I. Chemical contaminants. J. AOAC Int. 76, 1193-1205.

Chen, T., Wu, Y., Zhang, X., Kong, Q., Song, S., Wang, L., et al., 1980. Improvement of cadmium contaminated soils at Zhangshi irrigation area and prevention of pollution in rice. J. Environ. Prot. Sci. 1, 7-11 (In Chinese).

Chen, X., Dong, W., Li, S., Qian, J., 1992. Study of Cd pollution in farmland soil of Hebei. Agro-Environ. Prot. 11, 202-205 (In Chinese)

Chen, H., Zheng, C., Tu, C., Zhu, Y., 1999. Heavy metal pollution in soil in China: status and countermeasures. Ambio 28, 130-134.

Chen, T., Shi, J., Liu, X., Wu, J., Xu, J., 2008. The spatial-temporal variability of vegetable soil heavy metals in the urban-rural transitional area of Hangzhou City. Acta Pedol. Sin. 45, 608-615 (In Chinese).

Cutler, D., Miller, G., 2005. The role of public health improvements in health advances: the twentieth-century United States. Demography 42, 1-22.

Deng, X., Shan, L., Zhang, H., Turner, N., 2006. Improving agricultural water use efficiency in arid and semiarid areas of China. Agric. Water Manag. 80, 23-40.

Dere, C., Lamy, I., Jaulin, A., Cornu, S., 2007. Long-term fate of exogenous metals in a sandy Luvisol subjected to intensive irrigation with raw wastewater. Environ. Pollut. 145, 31-40.

Ebenstein, A., 2012. The consequences of industrialization: evidence from water pollution and digestive cancers in China. Rev. Econ. Stat. 94, 186-201.

Eitan, O., Barchana, M., Dubnov, J., Linn, S., Carmel, Y., Broday, D.M., 2010. Spatial analysis of air pollution and cancer incidence rates in Haifa Bay, Israel. Sci. Total Environ. 408, 4429-4439.

El-Tawil, A., 2010. Colorectal cancer and pollution. World J. Gastroenterol. 16, 3475.

Ericksen, P.J., Ingram, J.S.I., Liverman, D.M., 2009. Food security and global environmental change: emerging challenges. Environ. Sci. Pol. 12, 373-377.

Fan, M., Shen, J., Yuan, L., Jiang, R., Chen, X., Davies, W.J., et al., 2011. Improving crop productivity and resource use efficiency to ensure food security and environmental quality in China. J. Exp. Bot. 63, 13-24.

FAO (Food and Agriculture Organization), 2010. Fewer Pesticides and Higher Yields and Incomes. FAO of the United Nations (http://www.fao.org/news/story/en/item/ $48883 /$ icode/)

Fu, G., 2012. Countermeasures for water and soil heavy metal pollution in China. China Environ. Sci. 32, 373-376 (In Chinese)

Galiani, S., Gertler, P., Schargrodsky, E., 2005. Water for life: the impact of the privatization of water services on child mortality. J. Polit. Econ. 113, 83-120.

Gallagher, L.G., Webster, T.F., Aschengrau, A., Vieira, V.M., 2010. Using residential history and groundwater modeling to examine drinking water exposure and breast cancer. Environ. Health Perspect. 118, 749-755.

Gao, H., 2013. Chinese government admits existence of cancer villages. Lancet Oncol. 14, 284.

Gao, Y., Yu, G., Luo, C., Zhou, P., 2012. Groundwater nitrogen pollution and assessment of its health risks: a case study of a typical village in rural-urban continuum, China. PLoS One 7, e33982.

Gong, G., Zhang, T., 2013. Temporal-spatial distribution changes of cancer village in China. Chin. J. Popul. Resour. Environ. 23, 156-164 (In Chinese).

Goodman, M., Naiman, J.S., Goodman, D., LaKind, J.S., 2012. Cancer clusters in the USA: what do the last twenty years of state and federal investigations tell us? Crit. Rev. Toxicol. 42, 474-490.

Grant, S.B., Saphores, J.-D., Feldman, D.L., Hamilton, A.J., Fletcher, T.D., Cook, P.L.M., et al., 2012. Taking the "waste" out of "wastewater" for human water security and ecosystem sustainability. Science 337, 681-686.
Grassini, P., Cassman, K.G., 2012. High-yield maize with large net energy yield and small global warming intensity. Proc. Natl. Acad. Sci. U. S. A. 109, 1074-1079.

Griffiths, D., 2007. China's ‘Cancer Villages' Pay Price. British Broadcasting Corporation News.

Hansen, E.S., Hilden, J., Klausen, H., Rosdahl, N., 2003. Wastewater exposure and health a comparative study of two occupational groups. Occup. Environ. Med. 60, 595-598.

Hassan, N.U., Mahmood, Q., Waseem, A., Irshard, M., Pervez, A., 2013. Assessment of heavy metals in wheat plants irrigated with contaminated wastewater. Pol. J. Environ. Stud. 22, 115-123.

He, G., 2013. Essays on the Health Effects of Pollution in China. University of California, Berkeley.

He, G., Zhang, L., Mol, A.P., Wang, T., Lu, Y., 2014. Why small and medium chemical companies continue to pose severe environmental risks in rural China. Environ. Pollut $185,158-167$.

Hendryx, M., Fedorko, E., Halverson, J., 2010. Pollution sources and mortality rates across rural-urban areas in the United States. J. Rural. Health 26, 383-391.

Hendryx, M., Conley, J., Fedorko, E., Luo, J., Armistead, M., 2012. Permitted water pollution discharges and population cancer and non-cancer mortality: toxicity weights and upstream discharge effects in US rural-urban areas. Int. J. Health Geogr. 11, 9-9.

Hu, C., Saseendran, S., Green, T., Ma, L., Li, X., Ahuja, L., 2006. Evaluating nitrogen and water management in a double-cropping system using RZWQM. Vadose Zone J. 5, 493-505.

Hu, X., Jiang, Y., Shu, Y., Hu, X., Liu, L., Luo, F., 2015. Effects of mining wastewater discharges on heavy metal pollution and soil enzyme activity of the paddy fields. J. Geochem. Explor. (in press).

Huang Y. EPA will accuse local governments being responsible for over ten million tons food is being polluted by heavy metals per year. Southern Daily; 2012. http:// epaper.nfdaily.cn/html/2012-03/09/content_7064951.htm. (In Chinese).

Huang, C., Wang, X., 2009. China's farmland sewage irrigation development and its impact on crop research. J. Anhui Agric. Sci. 37, 10692-10693 (In Chinese).

Huang, S., Jin, J., He, A., Tan, H., 2007. Regional differentiation and status of heavy metals in total soils under different patterns of land use. J. Agro-Environ. Sci. 26, 540-548 (In Chinese).

James, W., 2001. European diet and public health: the continuing challenge. Public Health Nutr. 4, 275-292.

Jiang, D., Wang, Z., Yang, J., Lu, J., Yang, D., 2012a. Overview and analysis of food chemical contaminant monitoring in 2000-2009 in China. Wei Sheng Yan Jiu 41, 204-208 (In Chinese).

Jiang, S., Shi, C., Wu, J., 2012b. Genotypic differences in arsenic, mercury, lead and cadmium in milled rice (Oryza sativa L.). Int. J. Food Sci. Nutr. 63, 468-475.

Jin, F., Wang, J., Shao, H., Jin, M., 2010. Pesticide use and residue control in China. J. Pestic Sci. 35, 138-142.

Kahn J, Yardley J. As China roars, pollution reaches deadly extremes. New York Times. 2007; 26:A1.

Kelepertzis, E., 2014. Investigating the sources and potential health risks of environmenta contaminants in the soils and drinking waters from the rural clusters in Thiva area (Greece). Ecotoxicol. Environ. Saf. 100, 258-265.

Khan, S., Cao, Q., Zheng, Y.M., Huang, Y.Z., Zhu, Y.G., 2008. Health risks of heavy metals in contaminated soils and food crops irrigated with wastewater in Beijing, China. Environ. Pollut. 152, 686-692.

Kingsley, B., Schmeichel, K., Rubin, C., 2007. An update on cancer cluster activities at the Centers for Disease Control and Prevention. Environ. Health Perspect. 115, 165-171.

Lake, I.R., Hooper, L., Abdelhamid, A., Bentham, G., Boxall, A.B.A., Draper, A., et al., 2012. Climate change and food security: health impacts in developed countries. Environ. Health Perspect. 120, 1520-1526.

Li, J., 2010. Water shortages loom as northern China's aquifers are sucked dry. Science 328, 1462-1463.

Li, X.M., Gan, Y.P., Yang, X.P., Zhou, J., Dai, J.Y., Xu, M.Q., 2008. Human health risk of organochlorine pesticides (OCPs) and polychlorinated biphenyls (PCBs) in edible fish from Huairou Reservoir and Gaobeidian Lake in Beijing, China. Food Chem. 109, 348-354.

Lin, B., 1997. Study of Cd pollution of soil-crop system in certain $\mathrm{Pb}-\mathrm{Zn}$ mine area, Guangxi. Chin. J. Soil Sci. 28, 235-237 (In Chinese).

Liu, L., 2010. Made in China: cancer villages. Environ. Sci. Policy Sustain. Dev. 52, 10-21.

Liu, J., Diamond, J., 2005. China's environment in a globalizing world. Nature 435 , 1179-1186.

Liu, H., Chen, H., Wang, X., 1995. Chinese total diet study in 1992 - pesticide residues. Wei Sheng Yan Jiu 24, 356-360 (In Chinese)

Liu, H., Probst, A., Liao, B., 2005. Metal contamination of soils and crops affected by the Chenzhou lead/zinc mine spill (Hunan, China). Sci. Total Environ. 339, 153-166.

Liu, P., Zhao, H., Wang, L., Liu, Z., Wei, J., Wang, Y., et al., 2011. Analysis of heavy metal sources for vegetable soils from Shandong Province, China. Agric. Sci. China 10 109-119.

Lohmar, B., Wang, J., Rozelle, S., Huang, J., Dawe, D., 2003. China's agricultural water policy reforms: increasing investment, resolving conflicts, and revising incentives. Agriculture Information Bulletin Number 782Economic Research Service, United States Department of Agriculture.

Massaquoi, L.D., Li, M., Wang, J., Ma, J., Yuan, M., Liu, D.-W., 2014. Mortality analysis on wastewater exposure in Shijiazhuang, Hebei, China, from 2007 to 2011. Int. J. Environ. Health Res. 1-14.

MEP\&MLR (Ministry of Environment Protection and Ministry of Land Resources of the People's Republic of China), 2014. Nationwide Soil Pollution Survey Report. http:// www.zhb.gov.cn/gkml/hbb/qt/201404/t20140417_270670.htm (In Chinese).

MEP (Ministry of Environmental Protection of the People's Republic of China), 2000. Report on the State of the Environment in China (In Chinese). 
MEP (Ministry of Environmental Protection of the People's Republic of China), 2013. Report on the State of the Environment in China. http://jcs.mep.gov.cn/hjzl/zkgb/ 2013zkgb/ (In Chinese).

MEP (Ministry of Environmental Protection of the People's Republic of China), 2014. Q\&A for Nationwide Soil Pollution Survey Report. http://www.zhb.gov.cn/gkml/hbb/qt/ 201404/t20140417_270671.htm (In Chinese).

Montesano, R., Hall, J., 2001. Environmental causes of human cancers. Eur. J. Cancer 37, S67-S87.

Naik, K.S., Stenstrom, M.K., 2012. Evidence of the influence of wastewater treatment on improved public health. Water Sci. Technol. 66, 644-652

NBS (National Bureau of Statistics of the People's Republic of China), 2013. National data. http://data.stats.gov.cn/workspace/index? $\mathrm{m}=$ hgnd (In Chinese).

Pan, J., Yang, Y., Gai, N., Wu, X., Lu, G., Wu, Z., 2011. Distribution of OCPs and PCBs in multimedium environmental samples from typical industrial and agricultural areas in Jilin Province, China. J. Agro-Environ. Sci. 30, 2210-2217 (In Chinese).

Peng, S., 2011. Water resources strategy and agricultural development in China. J. Exp. Bot. 62, 1709-1713.

Peng, P., Liao, X., Gong, H., Xiang, W., 1992. A study of pollution of heavy metal on paddy soil and brown rice in the middle of Hunan. Resour. Dev. Conserv. 8, 3-6 (In Chinese).

Piao, S., Ciais, P., Huang, Y., Shen, Z., Peng, S., Li, J., et al., 2010. The impacts of climate change on water resources and agriculture in China. Nature 467, 43-51.

Rahman, S., 2013. Pesticide consumption and productivity and the potential of IPM in Bangladesh. Sci. Total Environ. 445, 48-56.

Robinson, D., 2002. Cancer clusters: findings vs feelings. MedGenMed 4, 16-16.

Singh, A., Sharma, R.K., Agrawal, M., Marshall, F.M., 2010. Health risk assessment of heavy metals via dietary intake of foodstuffs from the wastewater irrigated site of a dry tropical area of India. Food Chem. Toxicol. 48, 611-619.

Sun, X., Ning, P., Tang, X., Yi, H., Li, K., 2012. Heavy metals migration in soil in tailing dam region of Shuikoushan, Hunan Province, China. Procedia Environ. Sci. 16, 758-763.

Sun, H., An, T., Li, G., Qiao, M., Wei, D., 2014. Distribution, possible sources, and health risk assessment of SVOC pollution in small streams in Pearl River Delta, China. Environ. Sci. Pollut. Res. 21, 10083-10095.

The State Council of China, 2013. Arrangement for soil environment protection and comprehensive treatment work in recent period. http://www.gov.cn/zwgk/2013-01/28/ content_2320888.htm (In Chinese).

The World Bank, 2006. Water Quality Management Policy and Institutional Considerations Discussion Paper. The World Bank, Washington, D.C. (http://www-wds. worldbank.org/external/default/WDSContentServer/WDSP/IB/2006/10/18/ 000310607_20061018111318/Rendered/PDF/ 377520CHA01Wat1management001PUBLIC1.pdf).

Thuy, P.T., Van-Geluwe, S., Nguyen, V.-A., Van-der-Bruggen, B., 2012. Current pesticide practices and environmental issues in Vietnam: management challenges for sustainable use of pesticides for tropical crops in (South-East) Asia to avoid environmenta pollution. J. Mater. Cycles Waste Manag. 14, 379-387.

UNESCO (United Nations Educational, Scientific and Cultural Organization), 2012. The Fourth United Nations World Water Development Report: Managing Water unde Risk and Uncertainty (WWDR4). UNESCO, Marseilles (http://www.unwater.org/ publications/world-water-development-report/en/).

USCDC (US Centers for Disease Control and Prevention), 2013. Cancer Clusters. NCEH (National Center for Environmental Health), USCDC (http://www.cdc.gov/nceh/ clusters/).

Wang, K., 1997. Status and countermeasure of Cd pollution in farmland of China. Agro-Environ. Prot. 16, 274-278.

Wang, K., Zhang, Y., 2007. Investigation and evaluation on Cd pollution of the acidic farmland soils irrigated with Cd-polluted wastewater for 25 years. J. Agro-Environ. Sci. 26 658-661 (In Chinese)

Wang, M., Wang, Z., Bao, D., Ran, L., 2002. Food contamination monitoring and analysis in 2000 in China. Chin. J. Food Hyg. 14, 3-8 (In Chinese).

Wang, M., Webber, M., Finlayson, B., Barnett, J., 2008a. Rural industries and water pollution in China. J. Environ. Manag. 86, 648-659.

Wang, Y., Sheng, L., Li, K., Sun, H., 2008b. Analysis of present situation of water resources and counter measures for sustainable development in China. Water Res. 19, 10-14.

Wang, J., Lin, C., Chen, Y., Liu, A., 2012. Cultivated land pollution at township level in China: situation, factors and measures. China Land Sci. 26, 25-30 (In Chinese).

Wang, J., Huang, J., Yan, T., 2013. Impacts of climate change on water and agricultural production in ten large river basins in China. J. Integr. Agric. 12, 1267-1278.

Watts, J., 2008. China's environmental health challenges. Lancet 372, 1451-1452.

Watts J. In China's 'cancer villages', residents pay the price for a dirty revolution. The Guardian. 2010:21.

Wei, B., Yang, L., 2010. A review of heavy metal contaminations in urban soils, urban road dusts and agricultural soils from China. Microchem. J. 94, 99-107.
Wei, T.Y., Cherry, T.L., Glomrod, S., Zhang, T.Y., 2014. Climate change impacts on crop yield: evidence from China. Sci. Total Environ. 499, 133-140.

WHO (World Health Organization), 1990. Public Health Impact of Pesticides Used in Agriculture. WHO, Geneva.

Wild, P., Ambroise, D., Benbrik, E., Tiberguent, A., Massin, N., 2006. Mortality among Paris sewage workers. Occup. Environ. Med. 63, 168-172.

Williams, P.N., Lei, M., Sun, G., Huang, Q., Lu, Y., Deacon, C., et al., 2009. Occurrence and partitioning of cadmium, arsenic and lead in mine impacted paddy rice: Hunan, China. Environ. Sci. Technol. 43, 637-642.

Wu, C., Maurer, C., Wang, Y., Xue, S., Davis, D.L., 1999. Water pollution and human health in China. Environ. Health Perspect. 107, 251.

Xia, Z., 1994. Regional differentiation of effect of heavy metals in soil on plant. Acta Ecol. Sin. 14, 102-105 (In Chinese).

Xia, Z., Li, S., 1985. Characteristic of the distribution of sewage irrigation in China and analysis of its cause of formation. Geogr. Res. 4, 40-45.

Xin, S., Li, H., Su, D., 2011. Concentration characteristics and historical changes of heavy metals in irrigation sewage in China. J. Agro-Environ. Sci. 30, 2271-2278 (In Chinese).

Xu, L., Luo, W., Lu, Y., Wang, T., Chen, C., Giesy, J.P., et al., 2011. Status and fuzzy comprehensive assessment of metals and arsenic contamination in farmland soils along the Yanghe River, China. Chem. Ecol. 27, 415-426.

Xu, L., Wang, T., Ni, K., Liu, S., Wang, P., Xie, S., et al., 2013. Metals contamination along the watershed and estuarine areas of southern Bohai Sea, China. Mar. Pollut. Bull. 74, 453-463.

Xu, X., Zhao, Y., Zhao, X., Wang, Y., Deng, W., 2014. Sources of heavy metal pollution in agricultural soils of a rapidly industrializing area in the Yangtze Delta of China. Ecotoxicol. Environ. Saf. 108, 161-167.

Yang, S., Song, T., 2007. Problems about usage of pesticide in China. Manag. Agric. Sci. Technol. 26, 42-45 (In Chinese)

Yang, Z., Liu, S., Zheng, D., Feng, S., 2006. Effects of cadmium, zinc and lead on soil enzyme activities. J. Environ. Sci. 18, 1135-1141.

Yu, J., Zhang, S., 2009. The Chinese cancer village phenomenon and its reflection of healthrelated environmental pollution problems. Proceedings of China Environmental Science Society Annual Conference (http://www.kadinst.hku.hk/sdconf10/Papers_PDF/ p166.pdf).

Yu, Y., Wang, B., Wang, X., Liu, W., Cao, J., Wong, M., et al., 2013. Temporal trends in daily dietary intakes of DDTs and HCHs in urban populations from Beijing and Shenyang, China. Chemosphere 91, 1395-1400.

Zeng, X., Li, L., Mei, X., 2007. Heavy metal content in soils of vegetable-growing lands in China and source analysis. Sci. Agric. Sin. 40, 2507-2517 (In Chinese).

Zeng, X., Xu, J., Huang, Q., Tang, S., Li, Y., Li, F., et al., 2013. Some deliberations on the issues of heavy metals in farmlands of China. Acta Pedol. Sin. 50, 186-194 (In Chinese).

Zhang, H., Shan, B., 2008. Historical records of heavy metal accumulation in sediments and the relationship with agricultural intensification in the Yangtze-Huaihe region, China. Sci. Total Environ. 399, 113-120.

Zhang, J., Mauzerall, D.L., Zhu, T., Liang, S., Ezzati, M., Remais, J.V., 2010. Environmental health in China: progress towards clean air and safe water. Lancet 375, 1110-1119.

Zhang, F., He, J., Yao, Y., Hou, D., Jiang, C., Zhang, X., et al., 2013. Spatial and seasonal variations of pesticide contamination in agricultural soils and crops sample from an intensive horticulture area of Hohhot, North-West China. Environ. Monit. Assess. 185, 6893-6908.

Zhang, X., Zhuang, D., Ma, X., Jiang, D., 2014. Esophageal cancer spatial and correlation analyses: water pollution, mortality rates, and safe buffer distances in China. J. Geogr. Sci. 24, 46-58.

Zhao, Y., Wu, Y., Wang, X., Gao, J., Chen, J., 2003. Study on of dietary pesticide residues in Chinese residents. Chin. J. Epidemiol. 24, 661-664 (In Chinese)

Zhao, J., Luo, Q., Deng, H., Yan, Y., 2008. Opportunities and challenges of sustainable agricultural development in China. Philos. Trans. R. Soc. Lond. Ser. B Biol. Sci. 363. 893-904

Zhao, K., Liu, X., Xu, J., Selim, H.M., 2010. Heavy metal contaminations in a soil-rice system: identification of spatial dependence in relation to soil properties of paddy fields. J. Hazard. Mater. 181, 778-787.

Zhao, Q., Wang, Y., Cao, Y., Chen, A., Ren, M., Ge, Y., et al., 2014. Potential health risks of heavy metals in cultivated topsoil and grain, including correlations with human primary liver, lung and gastric cancer, in Anhui province, Eastern China. Sci. Total Environ. 470, 340-347.

Zhou, P., Zhao, Y., Li, J., Wu, G., Zhang, L., Liu, Q., et al., 2012. Dietary exposure to persistent organochlorine pesticides in 2007 Chinese total diet study. Environ. Int. 42, 152-159.

Zhuang, P., McBride, M.B., Xia, H., Li, N., Li, Z., 2009. Health risk from heavy metals via consumption of food crops in the vicinity of Dabaoshan mine, South China. Sci. Total Environ. 407, 1551-1561. 